\title{
Contradictions of Ordered Trust: Trust-based Work and Conflicting Logics in Municipal Care'
}

I Helena Håkansson ${ }^{2}$

PhD Student, University of Gothenburg, Department of Sociology and Work Science, Sweden

\begin{abstract}
This article examines intra-organizational trust and institutional logics in municipal social care services in the setting of a trust-based developmental project. A case study was conducted in a Swedish municipal district. The data consists of 27 semi-structured interviews with care workers, first-line managers, and strategic staff as well as I I observations. The study adds insights regarding trust in public sector organizations and shows how a strong focus on economic efficiency can relativize trust into a question of financial accountability. The results demonstrate how the governing managerial logic is not only in conflict with but also seems to overrule attempts to establish a more trust-based logic. Moreover, contributing to the institutional logics literature, it further shows how power structures affect institutional logics and how conflicts between logics play out differently at various organizational levels. The prospects of accomplishing a more trust-based governance without larger institutional or organizational changes are hence problematized.
\end{abstract}

\section{KEYWORDS}

Care work / institutional logics / intra-organizational trust / municipal social care / public sector / Sweden / trust-based governance

\section{Introduction}

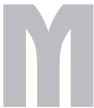

any Swedish municipalities are struggling with their budget as well as the retention and recruitment of care workers. In a situation where the needs are greater than the funding, one solution has been to increase efficiency with existing funds through, for example, new working methods within these organizations. In the Nordic countries, a great deal of faith has been put in employees' potential in terms of both solving current deficiencies and being drivers of organizational developments in public welfare organizations. Exactly how employees at the operational level should be able to carry out these measures within the boundaries of current resources and staffing is, however, rarely stated.

Since the 1990s, the umbrella concept New Public Management (NPM) has had a great impact on the governance of the public sector (Diefenbach 2009). Some of the fundaments of NPM are economic efficiency through control and target monitoring (Brante 2014), performance management, corporatization of units, resource allocation based on quantitative measurements, and parsimony with resources ('to do more with less') (Hood 1991). However, NPM has received substantial criticism, especially for leading to more administration and bureaucratization (Forssell \& Ivarsson Westerberg 2014; Hood 1991), as well as resulting in too much focus on measurable quantitative elements (Power 1997).

\footnotetext{
${ }^{1}$ You can find this text and its DOI at https://tidsskrift.dk/njwls/index.

${ }^{2}$ Corresponding author: helena.hakansson@gu.se.
} 
In Sweden, Denmark, and Norway, trust has become a central concept in efforts to de-bureaucratize and decentralize the public sector by promoting more trusting relationships both within and between different public sector organizations (Vallentin \& Thygesen 2017). Trust has metaphorically been called 'the Nordic gold' in a report by the Nordic Council of Ministers (Andreasson 2017). In Denmark, a trust-based reform was on the agenda as early as 2011 and since 2013, this reform has aimed at removing unnecessary controls and bureaucracy (Vallentin \& Thygesen 2017). In Norway, local initiatives to promote more trust-based governance have been initiated, such as the trust model in the city of Oslo in 2016 (Eide et al. 2017). Similar attempts have previously been on the agenda in Sweden as well under different labels, such as 'broad participation' or inclusion and participation (Svensson et al. 2007). Despite the emergent interest in trust as a governing technique, there is a lack of research on trust and control in public sector organizations (Vallentin \& Thygesen 2017). Furthermore, inter-organizational trust has gained more attention than intra-organizational trust (Grey \& Garsten 2001). There is an apparent contradiction in top-down trust-based initiatives at the operational level, where trust and control become intertwined. Despite this, the possibilities for trust in hierarchical organizations governed by control are rarely problematized in the literature. To bridge this gap, this article examines a trust-based developmental project in the social care services in a municipal district in Sweden.

The public sector is an arena of conflicting institutional demands, not least due to multiple logics, where none plays a dominant role, but several are in a position to affect and attempt to affect the organization (Pache \& Santos 2010). Institutional logics provide guidelines and norms on how to understand and behave in social situations, both for individuals and organizations (Greenwood et al. 2011). Understanding how different institutional logics relate to one another in an organization enables achieving an understanding of interrelationships and organizational behavior (Suddaby 2010). However, institutional theory has been criticized for neglecting and reproducing power structures (Munir 2015; Willmott 2015). Workers, conflicts of interests, and aspects of power have often been 'washed away' when applying an institutional perspective (Hirsch \& Lounsbury 2015; Munir 2015). Lok has therefore called for the development of a more critical institutional theory (2019). Examining institutional logics at different levels in the organization enables examining how power dynamics manifest themselves and materialize in trust-based work. Following this, by applying an institutional logics approach, the article aims to examine the prospects of trust-based governance in municipal care services through the case of a trust-based developmental project. Thus, the article is guided by the following research questions: How do institutional logics manifest in relation to a trust-based developmental project? And following this: how can intra-organizational trust be understood and explained through an institutional logics perspective?

\section{Background}

Social care in Sweden is a politically governed sector, where politicians in different committees and boards are ultimately responsible for the goals, guidelines, and decisions in social care services. The operational responsibility in public social care services is organized hierarchically from politicians at the national to the municipal level, followed 
by a number of middle-managers down to first-line managers and, finally, employees such as social workers, registered nurses, and assistant nurses. The position of assistant nurse working in home health care, home care for the elderly, and retirement homes is the most common occupation in Sweden, employing 135,300 individuals in 2018 (Statistics Sweden 2020a). Assistant nurses in these occupations work in several sectors, predominately with elderly individuals or individuals with disabilities. Given the current demographic changes, the prognosis for Sweden indicates a great need for additional welfare workers in the coming years. The group most affected by these demographic changes consists of care workers working with care of elderly people and people with disabilities; one estimation shows an increased need totaling around 100,000 additional employees by 2039 (Statistics Sweden 2020b). The Swedish government has stated that the staffing strategy for the future should not only focus on attracting and recruiting new employees, but also on retaining those already employed (Ministry of Health and Social Affairs 2017).

In 2016, the Swedish government appointed a delegation to investigate preconditions for increasing trust-based management in the public sector. The purpose for the investigation was to examine how public welfare management could be developed so as to 'a greater extent utilize the competence and experience of employees to achieve greater quality for citizens and companies' (SOU 2018, p. 4, my translation). The delegation identified a number of deficiencies, such as a lack of collaboration both within and between different public organizations, an increased and inefficient administration and target monitoring on goals that do not benefit the organization. These deficiencies, according to the delegation, are a result of governance and management. However, employees are highlighted as key to many of the solutions. The delegation states that employees, in addition to their core tasks, should involve citizens more in decisions, serve as 'co-leaders' with their managers, be involved in operational development, and assist in shaping the assignments of support functions (SOU 2018).

Such expectations on employees to assume greater responsibility beyond their core work tasks are in line with extended managerial expectations concerning participation and influence. However, while managers are more inclined to look upon participation and influence as conditions for increased responsibility, employees tend to intrinsically see them as values (Kilhammar 2011). Organizational and professional relations are constituted by institutional logics creating a framework that favors some ways of thinking while constraining others (Thornton et al. 2012). Different perceptions can thus be an expression of conflicting institutional logics, which also have the possibilities to affect the perception of trust at different organizational levels. These issues are at the center of this article.

\section{Theoretical framework}

\section{Institutional logics}

Institutional logics can be used to conceptualize different norms and actions at different levels in the organization and how they relate to each other (Thornton et al. 2012). Thornton and Ocasio (2008) define an institutional logic as 'the socially constructed, historical patterns of cultural symbols and material practices, including assumptions, 
values, and beliefs, by which individuals and organizations provide meaning to their daily activity, organize time and space, and reproduce their lives and experiences' (p. 103). The core idea is that the interests, identities, values, and assumptions of individuals and organizations are embedded in existing institutional logics. This creates an embedded agency based on partial autonomy (Thornton \& Ocasio 2008), where institutional logics can both enable and restrain actors' actions within organizations (Thornton et al. 2012). A focus on institutional logics can thus enhance the understanding of interplay and discrepancies within organizations, as well as organizational changes.

The logics of the market, professionalism, and bureaucracy have been identified as the main logics for the organization of work (Freidson 2001). The market logic is associated with a strong customer focus (Bévort \& Poulfelt 2015), the professional logic is based on professionalism and expert knowledge (Freidson 2001), while the bureaucratic logic is based on standardization, control, and regulations by managers (Liljenberg 2020). According to Freidson, the bureaucratic logic is synonymous with a firm logic, referring to 'all formal organizations which exemplify the managerial control of work' (2001, p. 4). Thus, the bureaucratic logic resembles the concept of managerial logic, which combines a focus on efficiency through standardizations and regulations with a strong focus on the customer (Andersson \& Liff 2018). The managerial logic is similar to the 'business-like health care' logic examined by Reay and Hinings (2009) and the managerial techniques used for control described by Martin and colleagues as a 'corporate logic' (2017). The prioritization of efficiency and control through managerialism has been enhanced by NPM (Scott 2021).

Previous research on the relationship between institutional logics has shown how conflicting logics can coexist, interact, and clash with each other (Bévort \& Poulfelt 2015; Liljenberg 2020; Martin et al. 2017; Reay \& Hinings 2009). According to some studies, actors can strategically use elements from different logics (Alvehus 2018; Andersson \& Liff 2018; Pache \& Santos 2013). On the contrary, others argue that there is a tendency to overestimate the degree of autonomy given to individual actors (Martin et al. 2017), as the most powerful actor defines the dominant logic (Greenwood et al. 2011). Hence, this may limit autonomy and agency depending on their position within the organization (Martin et al. 2017). Depending on actors' ability to obtain the power to act and to what extent they are affected by a new institutional logic, they will respond to change initiatives in different ways (Reay \& Hinings 2009). Employees having been socialized into a particular institutional logic will most likely defend it when it is challenged (Pache $\&$ Santos 2010). Hence, introducing trust-based governance in an organization may be affected by institutional logics and relations within the organization.

\section{Aspects of trust}

Two common forms of trust are generalized trust (also called social trust) and specific trust. Generalized trust concerns having faith in people we do not know, while specific trust assumes knowledge of the one who is to be trusted and emphasizes that trust is something earned (Uslaner 2002). Intra-organizational trust, which is in focus in this article, can be said to exist in the grey zone between generalized and specific trust, where trust often relates more to specific positions than to specific individuals. In this article, 
a neo-institutionalist perspective on trust is combined with a more power-oriented perspective (Reed 2001).

According to a neo-institutional perspective, trust is a product of intra-organizational conditions and internal relationships within the organization (Bachmann 2003). The propensity to trust is often explained at a personal level as 'the general willingness to trust others' (Mayer et al. 1995, p. 715). Between organizational levels (in larger organizational structures), however, this might be rephrased as the general willingness to trust a generalized other in another position. Something particularly important for intra-organizational trust is the presence of a world-in-common; that is, a shared understanding of social rules as the division of work, distribution of responsibilities, and agreement regarding work duties (Bachmann 2003). Trust in a superior is related to the degree to which institutional conditions/regulation of employment conditions are perceived as being enforced and fair (Oskarsson et al. 2009). Organizational trust from the employee's perspective can be defined as a feeling of confidence that the employer will be straightforward and follow through on commitments (Gilbert \& Tang 1998).

Trust is closely related to power and control (Grey \& Garsten 2001; Høyer \& Wood 2011; Oskarsson et al. 2009; Willemyns et al. 2003). According to Grey and Garsten (2001), trust can be seen as a sub-form of control. A highly complex aspect of work organizations concerns how to maximize regulations of work behavior while simultaneously ensuring that there is sufficient commitment among workers (Thompson 1989). Hence, an interest in intra-organizational trust can also be due to a strong focus on commitment as a governing function (Reed 2001). Regulations and control considerably reduce the risk of trust (that someone should behave in an unfavorable way) (Høyer \& Wood 2011). Hence, intra-organizational trust is to some extent based on regulations that reduce discretion (Fox 1974; Grey \& Garsten 2001). Since systems based on control also presuppose a lack of trust in employees, this can be considered a kind of mistrust-based trust and management based on heavy control functions as a form of 'mistrust-based management' (Høyer \& Wood 2011). However, the employment relationship is not unregulated. It can be described as an asymmetric relationship where specific exchanges and outcomes are regulated through the employment contract (Fox 1974). The employment relationship depends on the position in the organization, meaning that the 'mistrust-based trust' is asymmetrically distributed in relation to different categories of employees.

Trust is a more complex phenomenon compared to how it is generally perceived. By combining these two perspectives on trust, it is possible to examine trust in relation to both norms and the exercise of power. Applying an institutional logics perspective may enable a further problematization of intra-organizational trust and trust-based governance.

\section{Method}

This investigation is a case study of a project based on employee-driven, trust-based developmental work in social care services in a municipal district in Sweden. The data consists of interviews with care workers, first-line managers, strategic staff, and observations of lectures and work groups. A total of 27 interviews and 11 observations have been conducted over the period 2017-2019. 


\section{The trust-based development project}

The purpose of the project was to implement a working method called 'employee-driven innovation' (EDI), based on the Plan-Do-Study-Act method (Reed \& Card 2016). A central part of employee-driven innovations is employees being the drivers of developmental work through bottom-up processes (Høyrup 2010). In the project, small work groups of employees were supposed to work independently with smaller developments at unit level.

The project began with a short introduction to the EDI method where a template for how to use the method in practice was handed out. It then continued with a universitylevel training course given to the first-line managers and strategic staff in the project where topics such as 'creative problem solving' and 'take care of the employees' creativity' were mixed with group discussions. Throughout the course, the participants were encouraged to test the EDI method in their units and given opportunities to reflect on the progress. After completing the course, the participants were expected to continue using the method and pass on their obtained knowledge to their employees.

\section{Study sample and data collection}

A total of 19 first-line managers and strategic staff participated in the project, 12 of whom were included in the study. Due to the focus on care, a strategic sampling was carried out to only include those who worked with or toward social care in the study. This resulted in six strategic staff and six first-line managers being included. To capture different views within the organization, a choice was made to also include 10 care workers working at three of the units in the study. The first-line managers worked in elderly and disability care. During the course, all except one of the first-line managers tested the method. Afterward, one unit continued working according to the method for a while, one unit tested a limited version, and the remaining four units did not continue using the method at all. In pursuit of variety, the included care workers worked at the unit that used the method for a while, the unit that tested a limited version and one of the units that did not use the method at all. The strategic staff included worked toward social care in different ways. Two of them worked in HR at the district level, two worked with operational development at the district level and two worked with operational development at the city level. The strategic staff are not formally superior to the first-line managers and have no managerial responsibilities at the unit level. However, they do have a mandate to distribute work tasks, implement new working methods, and assemble control data for reports to higher levels.

The interviews lasted for 30-60 minutes. They were semi-structured and followed an interview guide. Seven individual interviews with care workers and one group interview with three care workers were conducted. The group interview was set up spontaneously, as the care workers preferred this to individual interviews. At the end of the project, follow-up interviews were conducted with the remaining five first-line managers (one had resigned during the project period). The observations were made during group discussions linked to the initial training for the strategic staff and first-line managers within the project, as well as in the work groups of care workers testing the method. Seven observations were made during the training, and four observations were 
conducted in work groups of care workers. The observations were conducted with a focus on the method and on how the participants related to, discussed, and perceived the project. The observations were mainly complementary to the interviews and have been useful for gaining knowledge regarding the conditions for conducting developmental work at the operational level.

\section{Analysis}

The method of using case studies in empirical inquiries is suitable for investigating a specific situation by drawing on various lines of evidence, the purpose being to address questions of 'how' or 'why' concerning the phenomenon of interest (Yin 2002). Data was collected during two years, some at the initial phase of the project and some at the end of it, which affected the research process in three ways. First, early findings from the initial observations guided the choice of including individuals from different levels in the organization and informed the interview guide. Second, since data was continuously analyzed, those early findings could be followed up and re-examined in the interviews. Third, as the project was followed from start to finish, knowledge of the entire process and not just the outcome enabled a more in-depth analysis of the trust-based developmental project. The observations were used both for contextualizing the interviews and analyzed as data.

The interviews were continuously transcribed and analyzed together with the field notes from the observations in ATLAS.ti, using thematic analysis in line with Graneheim and Lundman (2004). An initial coding was conducted with an open focus on recurrent topics, and the codes were then merged into themes relating to the aim of the study, such as 'conditions', 'experiences of the project', 'the view of each other'. In the last step, after all data had been collected, the themes were analyzed through the conceptual framework of trust and institutional logics. The institutional logics were thus captured by pattern inducing, where different logics were identified through a bottom-up process and then related to previous findings (Reay \& Jones 2016).

\section{Ethical considerations}

The research was conducted in accordance with the principles of the Swedish Research Council (2017) and was approved by the Regional Ethics Board in Gothenburg (Reg. no. 2016-07204). All participants were informed about the study, that participation was voluntary, that they could withdraw from the study at any time and ensured confidentiality. To ensure the participants' anonymity, all names were replaced during the transcription of the interviews. During the observations, no names were written down. For practical reasons, all care workers interviewed, except those in the group interview, were chosen by their first-line manager or volunteered to be interviewed when the first-line manager was present. In the group interview, the care workers were more critical than in the other interviews. The respondents who had been chosen by their first-line managers were less critical, albeit still not uncritical, thus suggesting that no major bias emerged from having the first-line managers select the interviewees. 


\section{Results}

The result section starts with a description of the project setting, illustrating the motives and expectations from the upper management in the district, the structure and framework of the project, while also presenting a brief summary of the outcome of the project. This is followed by an investigation of the institutional logics in the organization and their relationship. The final part shows how the dominant logic affected trust in general and the trust-based developmental work in particular.

\section{Implementation of the project}

Working with leadership and innovations was an overall theme in the municipal district. At a meeting for all managers, the district director explained that the focus on leadership and innovations aimed at creating cost-effective solutions for the future. The studied project was linked to this focus; however, cost-effectiveness was not highlighted in the project. Instead, increased participation and becoming a more attractive employer were emphasized rather than efficiency.

The core of the project method was to have small groups of care workers work independently with developmental work in their units. The care workers were to independently work with problems they wanted to change, plan, and test a development, evaluate it and then, if needed adjust it. If satisfied with the development, they were then meant to propose integrating it in their daily work to their first-line manager. After solving one problem, they were supposed to start over and repeat the procedure of solving one problem after another in their units. The role of the first-line manager was to create conditions enabling developmental work and to decide whether to sustain the developments.

When put into practice, the developments made within the project were modest in nature, focusing on improvements for care recipients at the unit level. Examples of such developments include refurnishing a room, creating a communication board for care recipients, making schedules for daily practices, and improving the introduction of temporary workers. There was great satisfaction in relation to the developments made both by first-line managers and by the care workers. Nevertheless, after the project ended, none of the included units continued to work according to this method.

\section{Logics at work}

In the interviews and observations conducted, two institutional logics were apparent in the organization and in the project: a managerial logic and a caring logic. The managerial logic refers to the logic guiding the entire organization. It was manifested through a focus on finances and control (Andersson \& Liff 2018; Martin et al. 2017) present at all levels in the organization. The managerial logic can be linked to a general managerial turn in the Swedish public sector, driven primarily by NPM (Scott 2021). With its focus on quantifiable measures and performance, managerialism is a central component in NPM (Scott 2021).

The care logic manifested itself through an emphasis on relational aspects and being sensitive to the specific needs of dependent care recipients, thus referring to concrete 
individual needs rather than articulated preferences (Vabø 2006; Wærness 1984). The caring logic can be linked to a professional logic. Professions require a higher education and involve working with tasks so specialized that they cannot be standardized (Freidson 2001). In this sense, none of the care work occupations in the study (assistant nurses and care assistants) can be categorized as professions. However, as they still expressed a strong professional ethos or caring rationale (Wærness 1984) linked to their professional identity as care workers (Dahl et al. 2015; Fincham \& Forbes 2015), the caring logic is here conceptualized as a form of professional logic.

A number of studies have focused on the conflict between different logics (Bévort \& Poulfelt 2015; Liljenberg 2020; Reay \& Hinings 2009). In this study, however, the two logics manifested themselves somewhat differently depending on the organizational level. All in all, the managerial logic conditioned the caring logic through the control over resources, affected trust between the strategic and operational levels and restricted the possibilities for a more trust-based governance.

\title{
Care in the care work
}

Among the care workers, a strong caring logic reoccurred both in the interviews and the observations. Their relationships with care recipients and improving the care given were important aspects of their entire work experience. The observations showed that when testing the developmental method in small work groups of care workers, a substantial amount of time and effort was put into adjusting developments to suit individual care recipients. The care workers were fond of working according to the project method but were unable to continue working in accordance with it due to a constant lack of care workers. One care worker explained how their staffing situation affected their ability to work with anything else than core tasks:

\footnotetext{
Right now, we are not working with any developmental work. Right now, we are surviving for a couple of months until everyone is replaced and the new group constellation is set. Now is not the time for that.
}

The care workers were generally dissatisfied with the terms of their work and how cutbacks affected the quality of the care that they were able to provide. They described a work situation characterized by a high level of turnover, sick leave, a lack of temporary workers, stress, and having to reduce the level of service that the care recipients were entitled to. One care worker described how they constantly had to prioritize the most vital care work due to permanent understaffing.

\begin{abstract}
We skip the shower. We skip laundry. We skip taking them out for a walk. We only do what is important when it is like that, medication, breakfast, lunch, that kind of stuff [...] If they have a shower once a week, we will have to move it to the next week because we don't have the time. Usually, there is a lack of staff the next day too, and that day is already planned.
\end{abstract}

The financial situation thus restrained the care that could be given. Despite the constant compromises regarding quality due to a lack of personnel, the care workers were very 
keen about the well-being of the care recipients. In the group interview, one of the care workers explained why they continued to work despite their dissatisfaction with the working conditions: 'We do it because we love the elders and get love back from them every day'. Among all care workers, similar statements were given on how the relationship with care recipients made their work meaningful. When asked about what they would like to develop if they had extensive opportunities, their wishes concerned accessibility, improving the environment for care recipients, workplace education in medicine and language courses for foreign-born colleagues. But first and foremost, the wishes centered on more staff. One care worker ironically suggested that something new to test could be to improve the staffing: 'We need to increase the staffing. There is too much to do. We have too many tasks. Maybe, they could try raising the staffing level if they are going to test new things'. The care logic was illustrated through ideals of care in the form of a responsiveness to care recipients which requires sufficient time and attention (Vabø 2006), and hence adequate staffing. However, the care logic was in constant negotiation with the economic framework of the organization, which the care workers could not affect. Instead, they were 'running faster' to provide care despite a strained situation in their efforts to adjust to the managerial logic guiding the work.

\section{Budget-controlled first-line managers}

The first-line managers voiced a work situation permeated by an economic rationale linked to the managerial logic. This was articulated in the individual interviews and in observations where the strategic staff was not present. The economic rationale manifested itself mainly through experiences of expectations to stay within the budget no matter what. A recurrent theme in the interviews with the first-line managers was that the budget and to stick to the budget were seen as overriding everything else. In their stories, they seemed to constantly have to juggle creative solutions to not exceed their strained budgets. The budget was set for one year at a time, with no possibility to set aside money if the unit performed well one year. If they did, their budget was instead adjusted accordingly, and their surplus money was used elsewhere in the organization. In addition, they got no extra funding during the budget year to cover for the employees on sick leave. One first-line manager described how having low costs for sick leave one year had a negative impact on the budget for the coming year:

\footnotetext{
I had very low, nice numbers, fantastic. That's when I discovered that it affected the budget, because then my budget for the new year was adjusted. And then one [care worker] got sick. I then had to pay both sick leave and a temp with the same money. After a while, we were one [person] short because there was no available temp. And then another one got sick. Then this crazy thing happened, because all of a sudden, the money ran out and I was told that I had to reduce staffing because I exceeded my budget. But I had just reduced the staffing because someone got sick and that's why the next [person] got sick.
}

The first-line manager explained how this resulted in a vicious circle; without the ability to hire temps during sick leave, more people got sick. When asked whether it was possible to get extra funding in such circumstances, she laughed resignedly upon answering 
with a firm no. This resonates with the corporatization of units and the 'to do more with less' rationale inherent in NPM, where economic efficiency hinders resource allocation (Hood 1991). The effect of this economic rationale, chronic understaffing, made it difficult for the first-line managers to prioritize working with the trust-based developmental project. They were preoccupied with making their areas of responsibility operate at a basic level, which made it hard for them to set aside time for developmental work. For some managers, it was difficult to set aside time to meet all their employees whatsoever, not least to work strategically. The two first-line managers in home care described how their financial model only considered the time spent with care recipients, thus limiting the possibilities for the employees to meet all together. As a consequence, the first-line managers had started to consider staff meetings as a cost. One of them explained that: 'It costs a lot to send all employees on training programs, because then you have to take in temps. Just having a staff meeting is costly'.

The first-line managers were strongly guided by the economic rationale inherent in the managerial logic; however, due to their position, they had limited agency to act otherwise (Martin et al. 2017). Several of the first-line managers questioned the strong financial control over their work and had thoughts regarding other ways of steering the organization financially. But when raising issues or asking for support regarding their daily work, they shared an experience of being told to 'just solve it'. Consequently, they had stopped asking their superiors for help unless they could provide a solution to the problem. Regarding developmental work among care workers, the managerial logic further manifested itself through a control focus. The first-line managers were positively inclined toward the idea of care workers conducting developmental work. However, they attempted to steer the developmental work in different ways despite the focus on employee independence. This was seen in how the first-line managers formulated development ideas beforehand, led and steered the innovation meetings and how they chose specific workers to work with developments. The control focus that limited the independence of the care workers in the project was justified by the strong focus on efficiency and cost control at the operational level.

\section{Strategical demands on responsibility}

While the first-line managers were occupied with staying within the budget, the strategic staff seemed to be more at a distance from the scarce economic realities. One HR employee said that budgets affected her work only indirectly since it affected the work at unit levels. The strategic staff thought that negative attitudes were the obstacle, rather than the budget situation per se posing any real problem. One operational developer discussed a situation with a first-line manager who rejected a development due to the financial situation: 'The first-line manager immediately said, "No this won't work" because of the budget. It feels like many first-line managers have an intrinsic conception that there is no money or something'. The strategic staff generally expressed a low understanding of the needs at the operational level and dismissed complaints regarding the budget situation, referring to them as 'elusive explanations'. Many individuals working strategically believed that first-line managers in general did not assume full responsibility for the budget, quality, development, or time management. One HR employee described this as a widespread problem: 
There are so many first-line managers who do not take full responsibility for the budget. For example, they don't even do a cost check in the salary system regarding the salaries they pay. They don't even check whether it looks right. What kind of behavior is that?

At the same time, in many cases, the operational developers did not know what had happened with the training and developmental work they had initiated at the operational level. However, one operational developer described how first-line managers did not take responsibility for changing things, hinting that it was a question of attitude rather than structural possibilities:

I have met quite a lot of managers, and I feel that many of them do not always see that they have a responsibility, they usually say "it is very complicated, it does not work" or "I cannot understand why we do it in this way." They do not see that they can do something about it themselves and influence the situation in some way.

Several of the individuals working strategically shared this view and justified a governance through control and sanctions by referring to a lack of responsibility at the operational level. This not only individualizes the problem of financial strains, turning it into an issue of attitude rather than of resources, but it also reiterates a control orientation, which might be due to the institutionalization of control systems at the administrative level in public organizations in recent decades (Høyer \& Wood 2011). Similar to the first-line managers, such views were mainly articulated in the individual interviews and in observations where the unit managers were not present.

The strategic staff also expressed strong concerns regarding the care recipients and underlined the importance of developments benefitting them. This concern did not extend to the care workers, nor did it incorporate any practices to improve the working environment for care workers or the situation at the operational level. This focus on the care recipients can be explained through their role as customers, which is an important element of the managerial logic (Andersson \& Liff 2018). However, while this was a strong concern among the strategic staff, the organizational structure in general limited their abilities to implement developments that lasted for longer than the project time.

The managerial logic permeated the work at all organizational levels but in different ways. There was a key difference between the dimensions of the managerial logic at the strategic level and operational level. The former focused on demanding responsibility, while the latter focused on handling (economic) responsibility and financial strains. The relationship between power and autonomy (Greenwood et al. 2011; Martin et al. 2017) manifested itself in how the strategic staff could relate relatively freely to the financial situation, while it created apparent tensions and obstacles in the daily work at the operational level.

\section{Trust at work}

As illustrated above, the managerial logic conditioned the material possibilities for engaging in developmental work at the operational level. The following sections show how it further conditioned trust within the organization, thus making trust a question of accountability. Trust and confidence not only manifested themselves differently at 
different levels within the organization but were also conditioned by the different positions within the organization (Fox 1974; Gilbert \& Tang 1998; Oskarsson et al. 2009).

\section{A breach of trust}

At the beginning of the project, there was disagreement regarding one of its core premises. The first-line managers recounted how they had been told that they would get extra resources for participating in the project. However, when the project started, they were told that they had to set aside time for developmental work in their ordinary work schedule and their regular budget. This was seen as a betrayal of trust among the firstline managers. One manager described how this change limited her ability to implement the method at all due to the work situation at her unit:

That we, with the same staffing for the care work, should be able to add a meeting on developmental work for one hour once a week. It's not possible. I count time intervals of 15 minutes to solve the scheduling [...] And then during the fall, we've had an economic situation [which allows for] zero temps. We had to really cut down on everything, everything. Which means it hasn't been possible to say, "you have to be even fewer because I need someone at a meeting." That has not felt fully justified.

Another manager described how her high expectations of the project changed due to the new conditions: '... in the introduction to this, they first promised the moon and the stars, and then they withdrew and said "No, you have to solve this with the resources that you have." That's not possible'.

In contrast to the first-line managers' disappointment, the strategic staff argued that that the notion there would be extra resources for participating was a misunderstanding. As such, they had little understanding of the first-line managers' reactions. Even though the strategic staff themselves considered it too costly to train all employees in the project method (due to the cost of temps covering for those on training), they still considered financial constraints at the unit level to be subjective. One HR employee illustrated her view by a comparison with time in general, indicating that complaints at the operational level regarding the conditions for the project were, in fact, a question of priorities:

We have 24 hours in a day, the question is what we do with them [...] If you look at working time in the same way, it's not just about adding hours or creating more hours, it's about using the hours we have. And our managers are not really there yet, they don't yet think the right way. So that's a challenge in concrete terms.

The HR department initiated a project based on trust and then violated the core expectations of one of the participants, dismissing it as a misunderstanding and expecting the first-line managers to implement the trust-based working method anyway. However, this initial breach of trust, as it was perceived by first-line managers, had implications for the remainder of the project. The project had a motto, 'dare to fail', which was emphasized by both first-line managers and strategic staff. Despite this, none of the first-line managers who had opted out of the method informed the project management. Instead, they turned down their loud protests against the changed conditions 
and kept on participating in the meetings, discussing general issues, without informing or explaining that they were no longer using the project method. Despite the project motto, they did not seem willing to acknowledge the 'failure' of not implementing the method. The strong financial control created a silence among the first-line managers, which disrupted the entire implementation of the trust-based project. This silence of the first-line managers can thus be seen as a manifestation of a lack of trust, which can be linked to their previous experiences of a lack of feedback when raising issues (Oskarsson et al. 2009).

\section{Distrust in the trust-based project}

Somewhat contradictory to the intentions of the project, the strategic staff expressed distrust in employees' abilities and motives for developments. They were concerned that employees would try to make things better for themselves, rather than making improvements for the care recipients. One operational developer stressed the importance of restraining care workers from carrying out developments that would only benefit themselves:
So, it's not the unit's need or making things better for yourself that guides the develop- mental work. That things get better for [the employees] might not mean they get better for those we work for [...] It might not always be that a solution that is very good for the care recipients is the best for the worker. So, there can be conflicts of interest. From a management perspective, we have to be very clear that the focus is on the care recipients.

The possible benefit of improvements that would benefit both workers and care recipients was not elaborated upon by the strategic staff. They deemed that the working environment should be good but not at the expense of the care recipients. Their rationale highlighted a dichotomy where the well-being of care workers and care recipients was constructed as conflicting. The prioritization of care recipients in the strategic functions further resonates with larger developments in the welfare sector, in which welfare recipients are constructed as customers to be satisfied with the services provided by the state (Vabø 2006). In contrast to the trust-based project they participated in, the strategic staff rather saw the care workers through a lens of distrust. One HR employee thought that workers often forgot why they are at work:

I mean, I am at work because I have a work assignment that needs to be done, and then I should have a good working environment and all that. But sometimes, things go wrong, it goes in the other direction, that having a good time at work becomes more important than that the work is executed well. Unfortunately, you often see that.

In contrast to the strategic staff, the first-line managers appreciated change initiatives from care workers; not only because these initiatives were considered easier to implement, but also due to the care workers' knowledge of the care recipients' needs. However, several first-line managers differentiated between different kinds of care workers, viewing them as varying in their ability to assume the responsibility of developmental work. The first-line managers who did so were not only the ones who tried to steer 
the developmental work the most, but also the ones who expressed the most concern regarding their budget situations.

Attitudes such as the ones described are rather a result of control aspects in the managerial logic and the organizational structure with sparse contact between different levels than due to interpersonal relations within the organization (Forsberg Kankkunen 2010). Several individuals working at the strategic level had a distant relation to the operational work. This seemed to affect their view on the contact between workers and care recipients and, hence, the concern of whose interests should be prioritized. Conversely, most of the care workers had no idea who worked at the strategic level. The care workers did not know their names and said that they would not recognize them even if they saw them. One care worker ironically commented on the lack of contact: 'It would have been interesting if the person who is going to develop the operational level had some contact with the operational level'. Instead of a 'world-in-common' (Bachmann 2003), it was rather a question of several worlds within the organization.

\section{Damned if you dare, damned if you don't}

In relation to the project motto 'dare to fail', several members of the strategic staff thought that first-line managers had to dare more, while at the same time deeming them irresponsible if they made the wrong decisions. One operational developer expressed that the first-line managers should dare more to show that everyone can fail, while at the same time problematizing that they got away too easily if exceeding the budget:

Sometimes, you have to be a bit brave as a manager and show your employees that you can also fail or make the wrong decision. Then you show that everyone has the right to fail.

I think it is unusual, but I believe that there are managers who systematically exceed their budgets because they know that someone else will solve it. If you just get a small slap on the wrist and someone else solves it, then you get away with it.

Another operational developer differentiated between small and large failures in relation to the motto: '... I think it is important to differentiate between big and small failures, to not test crazy things in the wrong area that can lead to big losses or risks'. Economic failures were thus just failures, and nothing encouraged dare to do. The project motto to dare more was thus limited to daring the right thing, which meant excluding financial risks and increasing costs. The differentiation between different kinds of failures further shows how the managerial logic relativized trust, turning it into a moral responsibility to keep the budget. This attitude can be traced to how an interest in cost-effectiveness influenced the decision of upper management to implement the project to begin with. With the aim to lower costs, there is no room for increased expenses. This, in turn, limited the developmental work at the unit level to no cost at all.

Trust within the organization was affected by previous experiences, position, and the managerial logic. Despite the focus of the project, previous experiences hampered trust among both first-line managers and the strategic staff. Trust is a relational phenomenon that needs to be of mutual concern in order not to erode, as trust elicits trust and 
distrust elicits distrust (Fox 1974). Among the first-line managers this led to a charade where they pretended to work more actively with the project than they actually did. Due to the strong focus on finances inherent in the managerial logic, trust was first and foremost turned into a question of efficiency and cost reduction. For the first-line managers, struggling with their budgets in the first place, this not only constrained their material possibilities to participate but also minimized their trustworthiness in the eyes of the strategic staff.

\section{Discussion and conclusion}

In light of the Nordic high-trust institutional context and a trust-based form of governance being sanctioned at the state level in Sweden, the difficulties in terms of implementing the trust-based project appear to be a paradox. However, as one of the countries most impacted by NPM (Scott 2021), there might be a need for a downshift in the focus on financial control before attempts to reform the public sector through more trusting relationships can succeed. Through the case of a trust-based developmental work project in municipal care services in Sweden, several tensions in trust-based work have been emphasized. The results highlight difficulties related to implementing trust-based developmental work, as power and control complicate the prospects of creating a more trust-based logic.

The article contributes with insights on how institutional logics are manifested and related to power structures in the organization. Where previous studies have shown how conflicting logics coexist, interact and clash (Bévort \& Poulfelt 2015; Liljenberg 2020; Martin et al. 2017; Reay \& Hinings 2009), a major contribution of this article is also how different aspects of the same logic played out differently depending on organizational position. In particular, this created tensions at lower hierarchical levels, showing how agency and autonomy are strongly related to someone's position in the organization (Greenwood et al. 2011; Martin et al. 2017). While there was room for agency among the strategic staff (cf. Bévort \& Suddaby 2016), agency at the operational level was to a greater extent limited by the financial framework.

The managerial logic relativized trust into a question of financial accountability, thus turning trust into a moral responsibility to act a certain way. This was amplified by the organizational structure, which seemed to construct different worlds within the organization (Andersen \& Westgaard 2015; Bachmann 2003; O'Brien-Pallas et al. 2006). This was most clearly seen in how, despite the project aim of being a more attractive employer, the strategic staff worried that the developmental work would be used to improve the care workers' working conditions at the expense of the care recipients. This conflict of interest occupying the strategic staff can be understood as a conflict between a logic where efficiency is gained by minimizing discretion (Freidson 2001) and the discretionary aspects inherent in the trust-based working method. It can be related to how institutional logics create different 'scripts' related to the professional identity of different actors, which are difficult to change (cf. Bévort \& Suddaby 2016). Since the strategic staff usually work both with organizational development and control, their reluctance toward the trust-based developmental project can be seen as a way of defending the logic they have been socialized into (Pache \& Santos 2010). It also echoes Fox's (1974) argument how the employment relationship and the structuring of work create 
an imbalance in reciprocity as different positions within the work organization are associated with different expectations in the form of exchanges, the regulation of work and judgment of mistakes. Whereas high-discretionary roles are linked to high levels of trust, low-discretionary roles are associated with low levels of trust. Thus, power is essential in the creation of categories of those who are seen as trusted or distrusted, thereby enabling 'the few to manifest distrust toward the many' (Fox 1974, p. 14).

A key precondition for trust-based developmental work is to allow employees to work independently (Høyrup 2010). This requires trust and less control, both in the project and in the organization at large. A contradiction concerning both trust-based management and trust-based developmental work is that both concepts are based on ordered trust and ordered engagement. Trust-based developmental work is thus a form of top-down controlled bottom-up work. Ordering trust in the first place can be seen as a logical impossibility, as trust cannot be created as a one-way form of communication by the upper management (Grey \& Garsten 2001; Willemyns et al. 2003). As seen in the case with the 'broken trust', there is a mutual dimension of trust that, together with previous experiences (Grey \& Garsten 2001; Oskarsson et al. 2009) among 'the many' at the operational level, can affect the outcome of trust-based governance. Consequently, it is difficult to implement a trust-based working method at the operational level when the organization is governed by a managerial logic mainly focusing on control and efficiency. Without larger organizational or institutional changes, trust-based governance can rather be understood as a continuation of NPM governance than a shift to something else.

\section{Acknowledgments}

I am grateful to the Swedish Social and Working Life Foundation for financial support (Reg. no. 2017-00030, 2016-00484, 2013-2300).

\section{References}

Alvehus, J. (2018). Conflicting logics? The role of HRM in a professional service firm, Human Resource Management Journal 28(1): 31-44. doi: https://doi.org/10.1111/17488583.12159 .

Andersen, G. R., \& Westgaard, R. H. (2015). Discrepancies in assessing home care workers' working conditions in a Norwegian home care service: Differing views of stakeholders at three organizational levels, BMC Health Services Research 15: 286. doi: https://doi. org/10.1186/s12913-015-0945-6.

Andersson, T., \& Liff, R. (2018). Co-optation as a response to competing institutional logics: Professionals and managers in healthcare, Journal of Professions and Organization 5(2): 71-87. doi: https://doi.org/10.1093/jpo/joy001.

Andreasson, U. (2017). Tillid - det nordiske guld (Trust - the nordic gold), Copenhagen: Nordisk Ministerråd. doi: https://doi.org/10.6027/ANP2017-744.

Bachmann, R. (2003). Trust and power as means of co-ordinating the internal relations of the organization: A conceptual framework. In Nootebom, B. \& Six, F. (Ed.) The Trust Process in Organizations: Empirical Studies of the Determinants and the Process of Trust Development, Northampton: Edward Elgar Publishing. doi: https://doi.org/10.4337/9781843767350. 
Bévort, F., \& Poulfelt, F. (2015). Human resource management in professional services firms: Too good to be true? Transcending conflicting institutional logics, German Journal of Human Resource Management 29(2): 102-130. doi: https://doi.org/10.1177/23970022 1502900204.

Bévort, F., \& Suddaby, R. (2016). Scripting professional identities: How individuals make sense of contradictory institutional logics, Journal of Professions and Organization 3(1): 17-38. doi: https://doi.org/10.1093/jpo/jov007.

Brante, T. (2014). Den professionella logiken: Hur vetenskap och praktik förenas i det moderna kunskapssamhället (The professional logic: How science and practice are united in the modern knowledge society), Stockholm: Liber.

Dahl, H. M., Eskelinen, L., \& Hansen, E. B. (2015). Coexisting principles and logics of elder care: Help to self-help and consumer-oriented service?, International Journal of Social Welfare 24(3): 287-295. doi: https://doi.org/10.1111/ijsw.12141.

Diefenbach, T. (2009). New Public Management in public sector organizations: The dark sides of managerialistic 'enlightenment', Public Administration 87(4): 892-909. doi: https://doi.org/10.1111/j.1467-9299.2009.01766.x.

Eide, T., Nilsen, E. R., Gullslett, M. K., Olafsen, A. H., Aaberge, A. H., \& Eide, H. (2017). Tillitsmodellen - erfaringer med mini-pilotering av selvstyrende team i tre bydeler i Oslo kommune (The trust model - experiences of mini-pilots with self-governing teams in three districts of Oslo municipality), Skriftserien fra Høgskolen i Sørøst-Norge Vol. 13, Drammen: University of South-Eastern Norway.

Fincham, R., \& Forbes, T. (2015). Three's a Crowd: The Role of Inter-logic Relationships in Highly Complex Institutional Fields, British Journal of Management 26(4): 657-670. doi: https://doi.org/10.1111/1467-8551.12102.

Forsberg Kankkunen, T. (2010). Sociala relationer och makt i genusmärkta verksamheter (Social relationships and power in gender-marked businesses), In Bejerot, E. \& Härenstam, A. (Ed.) Sociala relationer i arbetslivet (Social relations in working life), Malmö: Gleerups.

Forssell, A., \& Ivarsson Westerberg, A. (2014). Administrationssamhället (Administration Society), Lund: Studentlitteratur.

Fox, A. (1974). Beyond Contract: Work, Power and Trust Relations, London: Faber \& Faber.

Freidson, E. (2001). Professionalism: The Third Logic, Cambridge: Polity Press.

Gilbert, J., \& Tang, T. L.-P. (1998). An examination of organizational trust antecedents, Public Personnel Management 27(3): 321-338. doi: https://doi.org/10.1177/009102609802700303.

Graneheim, U. H., \& Lundman, B. (2004). Qualitative content analysis in nursing research: Concepts, procedures and measures to achieve trustworthiness, Nurse Education Today 24(2): 105-112. doi: https://doi.org/10.1016/j.nedt.2003.10.001.

Greenwood, R., Raynard, M., Kodeih, F., Micelotta, E. R., \& Lounsbury, M. (2011). Institutional complexity and organizational responses, Academy of Management Annals 5(1): 317-371. doi: https://doi.org/10.1080/19416520.2011.590299.

Grey, C., \& Garsten, C. (2001). Trust, Control and Post-Bureaucracy, Organization Studies 22(2): 229-250. doi: https://doi.org/10.1177/0170840601222003.

Hirsch, P. M., \& Lounsbury, M. (2015). Toward a more critical and 'powerful' institutionalism, Journal of Management Inquiry 24(1): 96-99. doi: https://doi.org/10.1177/10564 92614545297.

Hood, C. (1991). A public management for all seasons?, Public Administration 69(1): 3-19. doi: https://doi.org/10.1111/j.1467-9299.1991.tb00779.x.

Høyer, H. C., \& Wood, E. M. (2011). Trust and Control: Public Administration and Risk Society, International Journal of Learning and Change 5(2): 178-188. doi: https://doi.org/ 10.1504/IJLC.2011.044209. 
Høyrup, S. (2010). Employee-driven innovation and workplace learning: Basic concepts, approaches and themes, Transfer: European Review of Labour and Research 16(2): 143-154. doi: https://doi.org/10.1177/1024258910364102.

Kilhammar, K. (2011). Idén om medarbetarskap: En studie av en idés resa in i och genom två organisationer (The notion of employee-ship: A study of an idea's journey into and through two organizations). Dissertation, Linköping: Linköpings universitet.

Liljenberg, M. (2020). Drivers of Improvement at Local Level - Tension and Support from Coexisting Logics, Scandinavian Journal of Educational Research. doi: https://doi.org/ 10.1080/00313831.2020.1788157.

Lok, J. (2019). Why (and How) Institutional Theory Can Be Critical: Addressing the Challenge to Institutional Theory's Critical Turn. Journal of Management Inquiry 28(3): 335-349. doi: https://doi.org/10.1177/1056492617732832.

Martin, G., Currie, G., Weaver, S., Finn, R., \& McDonald, R. (2017). Institutional Complexity and Individual Responses: Delineating the Boundaries of Partial Autonomy, Organization Studies 38(1): 103-127. doi: https://doi.org/10.1177/0170840616663241.

Mayer, R., Davis, J., \& Schoorman, F. (1995). An Integrative Model of Organizational Trust, The Academy of Management Review 20(3): 709-734. doi: https://doi.org/10.2307/258792.

Ministry of Health and Social Affairs (2017). Framtidens äldreomsorg - en nationell kvalitetsplan, skr 2017/18:280 (The elder care of the future - a national quality plan), Stockholm: Government Office of Sweden.

Munir, K. A. (2015). A Loss of Power in Institutional Theory, Journal of Management Inquiry 24(1): 90-92. doi: https://doi.org/10.1177/1056492614545302.

O'Brien-Pallas, L., Duffield, C., \& Hayes, L. (2006). Do we really understand how to retain nurses?, Journal of Nursing Management 14(4): 262-270. doi: https://doi.org/ 10.1111/j.1365-2934.2006.00611.x.

Oskarsson, S., Svensson, T., \& Öberg, P. (2009). Power, Trust, and Institutional Constraints: Individual Level Evidence, Rationality and Society 21(2): 171-195. doi: https://doi. org/10.1177/1043463109103898.

Pache, A.-C., \& Santos, F. (2010). When worlds collide: The internal dynamics of organizational responses to conflicting institutional demands, Academy of Management Review 35(3): 455-476. doi: https://doi.org/10.5465/AMR.2010.51142368.

Pache, A.-C., \& Santos, F. (2013). Inside the hybrid organization: Selective coupling as a response to competing institutional logics, Academy of Management Journal 56(4): 972. doi: https://doi.org/10.5465/amj.2011.0405.

Power, M. (1997). The Audit Society: Rituals of Verification, Oxford: Oxford University Press.

Reay, T., \& Hinings, C. R. (2009). Managing the Rivalry of Competing Institutional Logics, Organization Studies 30(6): 629-652. doi: https://doi.org/10.1177/0170840609104803.

Reay, T., \& Jones, C. (2016). Qualitatively capturing institutional logics, Strategic Organization 14(4): 441-454. doi: https://doi.org/10.1177/1476127015589981.

Reed, J. E., \& Card, A. J. (2016). The problem with Plan-Do-Study-Act cycles, BMJ Quality \& Safety 25(3): 147-152. doi: https://doi.org/10.1136/bmjqs-2015-005076.

Reed, M. (2001). Organization, Trust and Control: A Realist Analysis, Organization Studies 22(2): 201-228. doi: https://doi.org/10.1177/0170840601222002.

Scott, D. (2021). (Dis)assembling Development: Organizing Swedish Development Aid through Projectification. Dissertation, Karlstad: Karlstads universitet.

SOU (2018). Med tillit växer handlingsutrymmet - tillitsbaserad styrning och ledning av välfärdssektorn (With confidence the scope for action grows - trust-based governance and management of the welfare sector), Swedish Government Official report, SOU 2018:47, Stockholm: Ministry of Finance. 
Statistics Sweden [SCB] (2020a). The Swedish Occupational Register with Statistics 2018, Official Statistic Sweden. Statistical Report: AM 33 SM 2001, Stockholm: SCB.

Statistics Sweden [SCB] (2020b). Trender och prognoser 2020. Befolkning, utbildning och arbetsmarknad i Sverige med sikte på år 2035 (Trends and Forecasts 2020 - population, education and labour market in Sweden, outlook to year 2035) Statistical Report: AM85 - Trender och Prognoser, SCB: Stockholm.

Suddaby, R. (2010). Challenges for Institutional Theory, Journal of Management Inquiry 19(1): 14-20. doi: https://doi.org/10.1177/1056492609347564.

Svensson, L., Aronsson, G., Randle, H., \& Eklund, J. (2007). Delaktighet i hållbart arbetsliv: Projekt som gästspel eller strategi i hållbar utveckling (Participation in sustainable working life: Projects as special performances or strategies in sustainable development), Malmö: Gleerups Utbildning.

Swedish Research Council (2017). Good Research Practice, Stockholm: Vetenskapsrådet.

Thompson, P. (1989). The Nature of Work, Basingstoke: Macmillan. doi: https://doi.org/10. 1177/017084069101200318.

Thornton, P. H., \& Ocasio, W. (2008). Institutional logics, In Greenwood, R., Oliver, C., Sahlin, K., \& Suddaby, R. (Ed.) The SAGE Handbook of Organizational Institutionalism, London: SAGE Publications. doi: https://doi.org/10.4135/9781849200387.

Thornton, P. H., Ocasio, W., \& Lounsbury, M. (2012). The Institutional Logics Perspective: A New Approach to Culture, Structure and Process, Oxford: Oxford University Press. doi: https://doi.org/10.1093/acprof:oso/9780199601936.001.0001.

Uslaner, E. (2002). The Moral Foundation of Trust, Cambridge: Cambridge University Press. doi: https://doi.org/10.1017/CBO9780511614934.

Vabø, M. (2006). Caring for people or caring for proxy consumers? European Societies 8(3): 403-422. doi: https://doi.org/10.1080/14616690600821990.

Vallentin, S., \& Thygesen, N. (2017). Trust and control in public sector reform: Complementarity and beyond, Journal of Trust Research 7(2): 150-169. doi: https://doi.org/10.1080/ 21515581.2017.1354766.

Wærness, K. (1984). The Rationality of Caring, Economic and Industrial Democracy 5(2): 185-211. doi: https://doi.org/10.1177/0143831x8452003.

Willemyns, M., Gallois, C., \& Callan, V. (2003). Trust me, I'm your boss: Trust and power in supervisor-supervisee communication, International Journal of Human Resource Management 14(1): 117-127. doi: https://doi.org/10.1080/09585190210158547.

Willmott, H. (2015). Why Institutional Theory Cannot Be Critical, Journal of Management Inquiry 24(1): 105-111. doi: https://doi.org/10.1177/1056492614545306.

Yin, R. K. (2002). Case Study Research: Design and Methods, Thousand Oaks, California: SAGE Publications. 